\section{Professor Sir Nevill Francis Mott}

\author{
CH, KB, ScD, FRS, Chevalier Ordre Nat. du Merite, Nobel Laureate in Physics
}

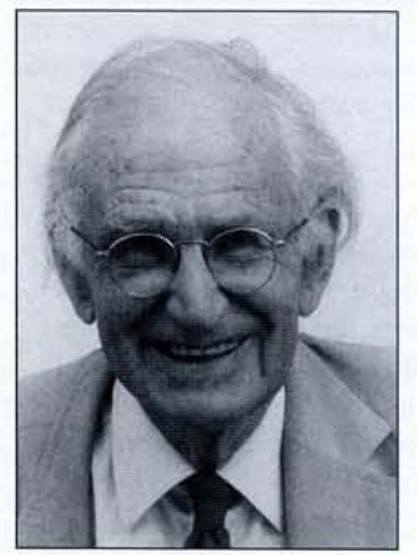

Born 30 September 1905, died 8 August 1996

The death of Sir Nevill Mott at age 90 brought to a close the illustrious "life in science" of a man who stood academically, as well as literally, head and shoulders above his contemporaries, many of whom were awed and inspired by his remarkable powers of intuition, his penetrating insight and his versatile creativity.

The staggeringly long length of his scientific career - his first paper was published in 1927 during the early days of quantum theory and his last on hightemperature superconductivity in 1996, four months after his death - must be unprecedented, and the range of his contributions to physics possibly unequalled. He was the author of at least fifteen books and over three hundred scientific papers, covering a range of topics as diverse as wave mechanics, nuclear physics, the properties of metals, ionic crystals, semiconductors and glasses, and the nature of superconductivity - an impressive list but, even so, one which does not convey or do justice to the range of his activities.

Nevill Mott was a theoretical physicist - a label far too narrow and restrictive to describe his output and methods of working. His principal posts were at Bristol and Cambridge but he was the "father" of a much larger community, communicating (without the benefit of email) with hundreds of scientists, theoreticians and experimentalists alike, in numerous countries - via handwritten letters most of which contained gems of ideas that were treasured by their recipients. Unlike most of us he didn't have a cluttered desk with a massive pile in the in-tray; he worked in "real time", writing first drafts of papers as ideas occurred to him and answering letters, responding to requests for information, and writing referee's reports, references etc., often by return post. His mind was his principal filing cabinet. In these ways he drew together ideas and people from different disciplines in a unique manner.

\section{Early years}

It was natural that Mott should take an early interest in physics. His mother and father both worked at the Cavendish Laboratory at Cambridge University with J.J. Thomson, a few years after J.J.'s identification of cathode rays with "corpuscles" (electrons) in 1897. In his autobiography "A Life in Science" he records that quite early in his life his parents communicated to him the excitement and importance of physics. His mother taught him at home until he was ten when he became a weekly boarder at a small preparatory school near Stafford. Before he left that school at age 13 he was, according to his own words, advanced in algebra and Latin and had been introduced to calculus. He spent the next five years as a boarder at Bristol's Clifton College, where a gifted teacher, $\mathrm{H}$. C. Beaven, instilled in him the beauty of mathematics. Later he recalled the excitement he felt when, at about age 16 , he realised why any number raised to the power nought equalled unity! In December 1923 he was awarded a major scholarship by St John's College, Cambridge, where he read for the mathematical tripos.

In spite of his mathematical ability, Mott was never tempted to be a pure mathematician; physics was his main interest. His first research was undertaken when he was an undergraduate. In the absence of any real suggestions from the head of theoretical physics at the Cavendish, Ralph Fowler, he set about finding his own problem which he decided should be on the application of wave mechanics to the scattering of charged particles - an active area of experimental investigation led by Ernest Rutherford. This work was published in the Proceedings of the Royal Society.

One year after he graduated with firstclass honours in 1928, Fowler arranged a grant to enable him to spend a year abroad, which he divided between visits to Copenhagen and Göttingen. At Copenhagen he discussed with Niels Bohr the startling prediction of Dirac in Cambridge that the electron carried a spin, and began work on a related problem. He clearly found it exciting to be in the company of Bohr and other famous scientists of the era - for example, Pauli, Gamow, Heisenberg and Hartree, who visited Bohr's famous institute. Before moving on to Göttingen, he returned for a few months to Cambridge where he solved an important problem relating to the scattering of alpha particles. Chadwick, Rutherford's second in command, was clearly impressed and took Mott along to see Rutherford who exclaimed "If you think of anything else like this, come and tell me." This was praise indeed and he later recalled it was on that day when he gained complete confidence in his ability to make a career in theoretical physics.

While in Göttingen, where he had hoped to work with Max Born - an opportunity that did not materialise owing to Born being in poor health - Mott received an offer of a lectureship at Manchester University under W.L. Bragg, which he accepted. A course of lectures he gave there on wave mechanics led to his first book "An Outline of Wave Mechanics" written at age 25. It was at Manchester where his interest turned to the properties of materials, stimulated no doubt by the power of the new technique of X-ray crystallography to determine the structure of solids - a method which earned W.L. Bragg (later Sir Lawrence and Cavendish Professor of Experimental Physics) the Nobel prize for physics, jointly with his father W.H. Bragg.

An invitation to return to Cambridge came in 1930 and Mott accepted a fellowship at Gonville and Caius College. Now married, he found that theoretical physicists were rather more respected than when he had first entered the Cavendish. Nevertheless, the prime interest there was still in atomic physics 
and 1932 was the Annus Mirabilis of the Cavendish, when the neutron was discovered, the atom split and the positron (positive electron), predicted by Dirac, was first observed. Stimulated by this extraordinary atmosphere and a suggestion by Fowler that he write a book on atomic collisions, Mott collaborated with Harrie Massey to produce a classic tome "The Theory of Atomic Collisions", which ran to several editions.

\section{Bristol}

In 1933, Mott accepted his first Chair, that of Professor of Theoretical Physics at Bristol University. For six years up to the outbreak of the Second World War, he played a significant role in establishing Bristol as one of the foremost centres for solid-state physics. His philosophy, which he never abandoned during the remainder of his life, was to have theoreticians and experimentalists working closely together.
Europe, particularly in Germany, by the application of quantum mechanics to the understanding of the properties of metals and of the difference between metals and semiconductors. The work of Sommerfield, Bloch, Peierls and Bethe was especially successful and Mott set about continuing this tradition. He found an enthusiastic supporter in Harry Jones, a former research student of Fowler's, and together they wrote a famous textbook "Theory of the Properties of Metals and Alloys". Strange as it may now seem to the hundreds of solid-state physicists who learned their basic quantum mechanics of solids from this work, the book was not that well received by other theorists, being criticised for lack of rigour. What in fact we see in this book is mathematics applied to the direct interpretation of experimental data, interspersed with bold initiative ideas which leapfrog the formal development when the rigorous mathe-

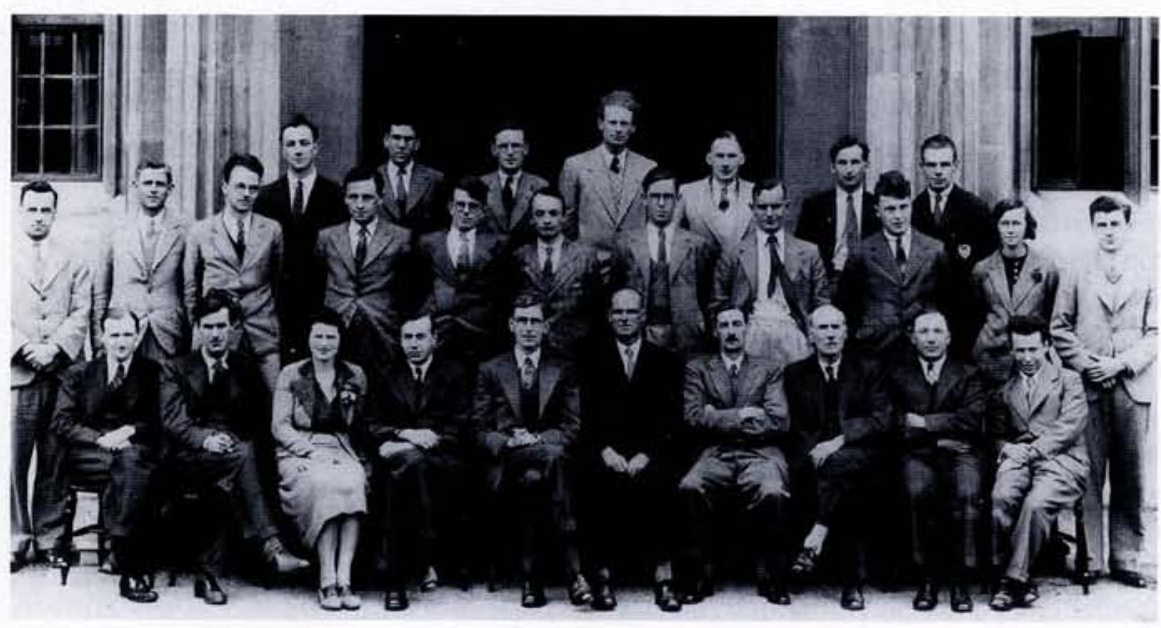

\section{Physics Department, University of Bristol, 1935}

Front row, reading left to right looking at the photograph: W. Sucksmith, H.W.B. Skinner, G.I. Harper, L.C. Jackson, N.F. Mott, A.M. Tyndall, S.H. Piper, I. Williams, H.H. Potter, W. Heitler.

Second row, reading left to right: ... Huntley, S.E. Williams, K. Fuchs, H. Jones, E.T.S. Appleyard, ... Baber, V.E. Cosslett, C.F. Powell, J.H. Burrow, K. Worsnop, A.F. Pearce.

Third row, reading left to right: R.W. Gurney, L. Frank, H. Worthy, W.R. Harper, ...Mercer, A.C.B. Lovell, N. Thompson.

Although many today see the advantages of such a liaison, it has never been easy to implement such a policy. Mott's ability to draw theory and experiment together, to persuade practitioners on both sides to work on common problems - indeed to blur any distinction between the two approaches - was one of his hallmarks for which he will be remembered. At Bristol, he deliberately avoided setting up separate departments for theorists and experimentalists, which was the norm elsewhere. Great success had been achieved in matical treatment fails. This type of pragmatic approach - annoying to some pure theoreticians but beloved by experimentalists anxious to have formulae with which to analyse their data - was to be seen again during Mott's career.

From recent accounts of members of the Bristol research group, Mott provided a stimulating atmosphere which they recall with fond memories. At miniconferences, which he organised with flair and a great sense of timing, participants were incited to perform at their best and many recall the excitement at these meetings. Numerous problems and puzzling properties of metals were solved at Bristol during those heady days advancing the subject and, at the same time, providing much of benefit to industrial metallurgists.

In those six pre-war years at Bristol, Mott did not confine his attention to understanding the physics of metals. He began his first work on semiconductors, a field with which he was to remain attached for many more decades - in fact, well into his retirement. The initial stimulus came from Ronald Gurney who had arrived from Manchester and who, like Mott, had a remarkable talent for visualizing solids in terms of their constituent atoms and electron waves, without the need for detailed mathematics. Together they wrote another "Mott and X" book (where in this case $\mathrm{X}$ was Gurney) titled "Electronic Processes in Ionic Crystals". Together they laid the foundation of the field of colour centres in alkali halides by providing a description of the defects involved in terms of negative ion vacancies. They also worked out the physics behind the photographic process why light falling on a grain of silver bromide was able to produce a speck of silver - the latent image. In 1940 Mott was awarded the Harker and Driffield medal from the Royal Photographic Society for this work. Four years earlier, at the age of 31, he had been elected a Fellow of The Royal Society.

Mott's personal qualities and humanitarianism were evident after the German occupation of Sudetenland, when there was a movement to rescue children of Jewish descent from Czechoslovakia. He and his wife, Ruth, with help from his sister, Joan, housed two young refugees, daughters of a Jewish musician. Lilly and Ilse Spielman, who stayed in England after the war, recall their gratitude to this day.

\section{The War and return to Bristol}

During the Second World War, Mott was involved in various defence projects relating to radar, shell fragmentation, the deployment of searchlights and to mathematical research on armaments generally. He succeeded Blackett as scientific adviser to a commanding officer in 1940. When he discovered that the number of enemy aircraft destroyed by British fire was being overestimated by quite a large factor, his commander told him that he must not disclose his findings until after the war was over! He wrote a 
paper on why German shells, which were made of steel with a high carbon content, fragmented into smaller pieces than the British shells. Apparently, a memorandum on this still survives in American ordnance laboratories. At about the same time, the Royal Society awarded him their prestigious Hughes medal for his work before the war.

In the last days of the war, Mott was offered chairs in Metallurgy and in Theoretical Physics at Cambridge, but an assurance that if he returned to Bristol he would succeed to Tyndall's position as head of department attracted him back there. He assumed the Headship in 1948 and immediately set about appointing new staff. Many of the scientists at Bristol before the war, e.g. Skinner, Gurney, Harry Jones, Heitler and Frölich, took positions elsewhere and did not return. In their place Mott engaged, amongst others, Jack Mitchell (now occupying a Chair at the University of Virginia) who demonstrated that, in the photographic process, silver precipitated preferentially along dislocations; Charles Frank, who produced novel theories of dislocations and crystal growth and predicted what became known as Frank-Read sources; Dirk Polder as a senior theorist; Jacques Friedel who married Mott's sister-in-law, before returning to France to become leader of solid state physics in Paris; and Nicolas Cabrera who worked with Mott on a theory of why aluminium and stainless steel do not rust. All these workers by their individual and joint efforts once again made the Bristol Physics Department into a leading research group. In 1949 Mott published his first paper on metal-insulator transitions - a topic which was to retain his interest to the end of his life. This was the period which saw the invention of the transistor at the Bell Telephone Laboratories in America and Mott took a keen interest in this development. He was later to propose a theory for what became known as MottSchottky barriers in semiconductors.

Administrative appointments slowed down Mott's personal research towards the end of his Bristol period (i.e. up to 1954). He became Dean of the Faculty of Science, served on government committees and was appointed President of the Physical Society overseeing its amalgamation with the Institute of Physics. He also took over the Editorship of the Philosophical Magazine and became Chairman of the Board of Taylor \& Francis, its publisher. Another activity which continued to occupy Mott's time for many years was his campaigning against the UK's development of the atomic bomb and his Chairmanship of the Atomic Scientists' Association, whose aims were to explain the true facts of nuclear energy to a wide audience and to investigate proposals for its control.

\section{Cavendish Professorship}

In 1953 Mott received an offer of the Cavendish Chair of Experimental Physics at Cambridge, following Sir Lawrence Bragg's retirement one year earlier. $\mathrm{He}$ recalls in his autobiography that he was not too happy at the thought of leaving Bristol but felt he could not turn down the offer to follow in the footsteps of James Clerk Maxwell, Lord Rayleigh, J J. Thomson, Ernest Rutherford and Lawrence Bragg - the previous holders of the prestigious Chair. It might seem strange that the title of Professor of Experimental Physics should be offered to a theorist but, apart from Rutherford, none of the previous incumbants had been principally experimentalists. One of Mott's first decisions, taken even before he actually took up the post, was to halt plans for the construction of a linear accelerator for high energy particle physics - not because he was against this type of research but simply because he did not see that the machine would be able to compete against similar American installations.

The move back to Cambridge in 1954 was Mott's last; he was to remain working there not only up to his official retirement in 1971 but for another twenty-five years thereafter. On his appointment, Professor Fred Seitz, the American solid-state physicist, wrote

\section{Dear Mott}

For several weeks there has been a consistent report that you have accepted the appointment as director of the Cavendish Laboratory. Deepest congratulations. During our sojourn in Tokyo I made bets with our colleagues that this would occur, since it was the most logical solution of the issue. Either my judgement is lucky or very profound.Undoubtedly, this means that you will be very busy during the summer and that we will catch only fleeting glimpses of you at the various meetings. In any case, we all hope that Bristol will manage to hold its level and remain the very fine center of research which you have made it.

Sincere regards

Frederick Seitz
That Cambridge was a world apart from Bristol became clear on Mott's introduction at the Cavendish. His first contact was with the Administrative Secretary of the Department. "What are your problems?" Mott asked of him. "Well Professor, I did want to talk to you about the Cavendish cricket match, academic staff versus assistants", came the reply.

Administrative duties and matters unrelated to his own research occupied Mott's attention for a great deal of his time as Cavendish Professor. Reform of the National Sciences Tripos, which permitted undergraduates to specialise in physics at an earlier stage of their studies than had been possible previously, was one of his missions. Another was to change the physical sciences curriculum in schools through the Nuffield Foundation. In chairing an advisory committee of that body he had to steer a difficult course between the protagonists of "learning by doing", which involved students being encouraged to discover the laws of physics for themselves mainly by experimental physics, and ideas based on his own education, in which the laws of physics are approached through mathematics, their validity and beauty becoming clearer when expressed and taught this way. A compromise was called for and to a large extent a successful solution found. As a member of the General Board and the Council of Senate, both influential bodies of the University, Mott steered through important decisions - not least the creation of the first science park by Trinity College which attracted science-based industries to the City. Most universities in the UK now have their own science park.

In 1959 Mott was elected Master of Gonville and Caius College. His predecessor, Sir James Chadwick, was a distinguished nuclear physicist who had discovered the neutron in 1932 and on whom cooperation between the USA and the UK in the Manhattan Project during the War virtually depended. Chadwick had retired prematurely following dissent within the College Fellowship and Mott was persuaded that he could heal the divisions that had developed. His appointment, as with Masterships of other Cambridge colleges, did not require him to resign the Cavendish Chair, but the task of holding the two positions must have been arduous. Life in Caius tended to centre around the Master's Lodge, a splendid place to entertain the many distinguished visitors. The lodge is situated within the College precincts opposite the chapel. 
Parts of it date from the sixteenth century and, in addition to wonderful dining and drawing rooms, it contains five bathrooms and a hatch leading into the college kitchens through which meals can be delivered. C.P. Snow's novels describe, with much reality, the intrigues and politics of college life, particularly in relation to the appointment of the Master. Mott used to say "He didn't know the half of it!" After six years of service, he resigned from the Mastership having become tired of the petty wranglings of some of the Fellows, just as his predecessor and indeed the founder of the College, John Caius, had done also. But this was not until after he had reformed the College's admission policy (at Cambridge, students are admitted to the University via the colleges), and arranged for the first time that Fellows could bring in lady guests to dine in Hall. During his tenureship, Mott continued his interest in control of nuclear weapons and hosted a Pugwash Conference in the College, at which he recalled Henry Kissinger arguing with the Russian representatives on their hostility to China. It was also during his Mastership of Caius that he was awarded his Knighthood.

\section{Non-crystalline solids}

When the present writer arrived in Cambridge in 1967, Mott was still Head of the Cavendish and had once again begun to turn his attention seriously to solidstate physics. His interest in metalinsulator transitions had never waned and when I described to him work I had been doing at the University of Illinois on heavily doped semiconductors, which behave as metals when the concentration of donors or acceptors exceeds a critical value, he displayed an interest far beyond my expectations, particularly as I had not been the first to make such measurements; Professor Fritzsche in Chicago and others had undertaken similar and more extensive studies. What Mott saw, with his customary and extraordinary insight, was that the metal-insulator transition in doped semiconductors was intimately related to a theoretical paper by Phil Anderson on the effect of disorder on the electronic states in a solid. Anderson's classic paper of 1958 (which he was later to describe as "one that is often quoted but seldom read") showed how disorder 'localizes' electronic states, distinguishing these from band-like 'extended' states. A metal-insulator transition occurs when the Fermi level passes through the energy separating extended from localized states. The disorder, in the case of heavily doped semiconductors, arises from the random positions of the donors and from the electric fields associated with charged compensating acceptors. Mott was able to show that the critical concentration of dopants for the 'Anderson transition' was not dissimilar to that for the 'Mott transition', the theory of which was based on a screening argument. In considering electrical conduction on the insulating side of the transition, he formulated what is now known as the Mott $\mathrm{T}^{-1 / 4}$ law which describes how carriers hop between localized states over a distance that is temperature dependent - so-called variable-range hopping. I recall his making a back-of-the-envelope derivation of this relationship, a calculation which was subsequently done "properly" but with essentially the same result. This was, however, only the beginning of a decade or more of activity on other disordered systems - in particular amorphous or non-crystalline semiconductors - which was eventually to lead to the award of the Nobel Prize for physics, which he shared in 1977 with Anderson and van Vleck.

It was an illuminating experience to see how Mott developed and nurtured the field of amorphous semiconductors. At the time, few groups showed any interest in them. Although the Xerox Corporation in America had achieved great success with their first "dry" photocopying machine which used amorphous selenium as the photoreceptor, the physics behind the process was not understood. In the Soviet Union, Kolomiets had been working on the properties of glasses; in Germany, Stuke had a small group and, in the UK, Spear was studying transport in thin films of germanium and silicon. What Mott did was to bring together these disparate activities using his by now well-tested methods. Pouncing eagerly on new results, he formulated his ideas on these and communicated them via his familiar handwritten letters to interested parties. He organised mini-conferences (in the way he had done at Bristol), visited lab-
Celebrating the announcement of the joint award of the 1977 physics Nobel prize to Sir Nevill Mott, van Vleck and P.W. Anderson.

On the left, Prof. Josef Stuke, head of the Marburg University physics group, with whom Mott collaborated for over 10 years in the field of amorphous semiconductors

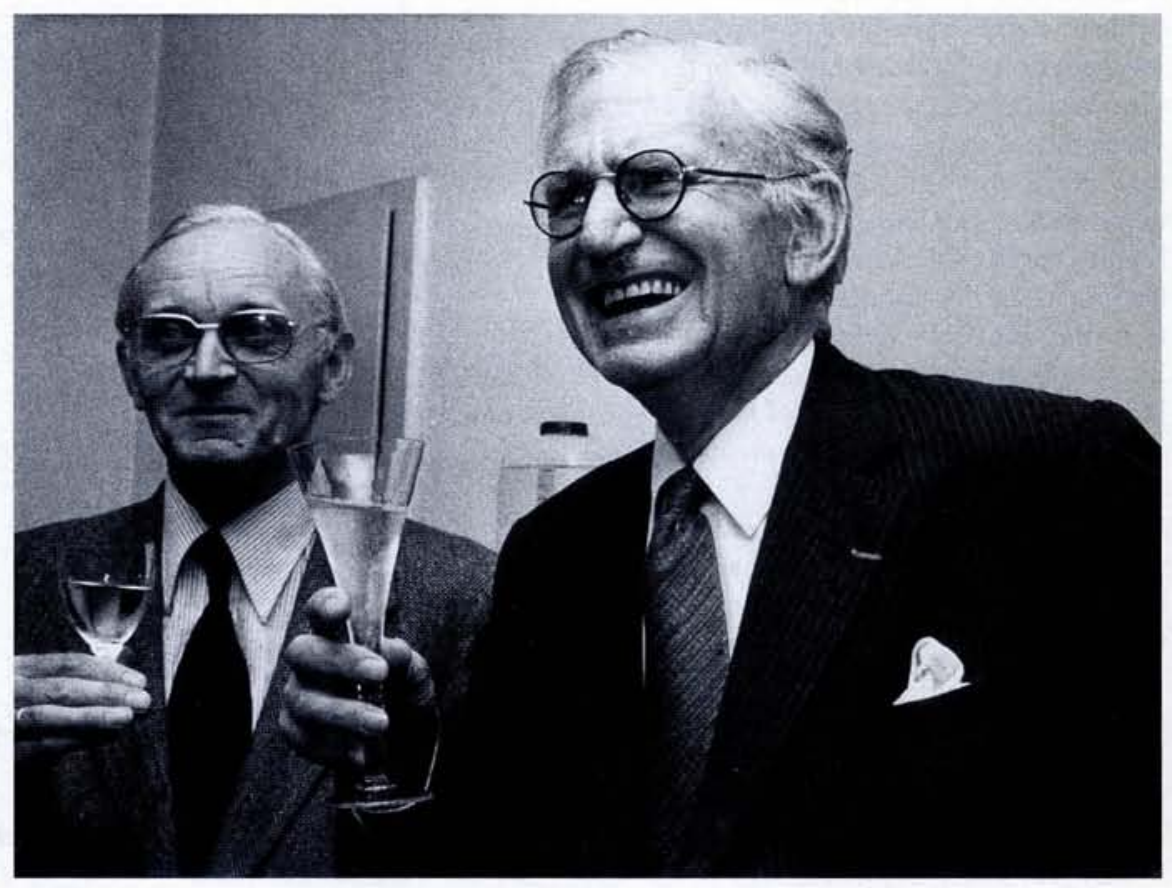


oratories for personal discussions, suggested $\mathrm{PhD}$ thesis topics, and wrote draft papers for wide circulation and comment. Thereby he rapidly became the father figure of a growing community and the Cavendish became the conduit through which ideas were channelled. During a visit to America he was introduced to Stan Ovshinsky who had started a small company in Detroit, Energy Conversion Devices (ECD), to exploit the potential of non-crystalline materials. Ovshinsky had developed two forms of electronic switch based on chalcogenide glasses - devices which, for the most part, were dismissed by other companies as being of little importance. But Mott thought otherwise and attempted to explain their behaviour in terms of his new concepts on conduction in disordered materials. The possibility of commercial utilization of amorphous semiconductors (whether it was to be fulfilled or not was of little consequence) had a dramatic influence on the growth of the field. The third conference in the series "International Conference on Amorphous and Liquid Semiconductors" (held every other year since 1965) took place in Cambridge and the number of participants was four to five times that of the previous meeting. Mott chaired most of the sessions, giving his own views and interpretation of virtually every paper presented. The concepts of mobility edges, hopping conduction, minimum metallic conductivity, the " $8-\mathrm{N}$ rule", relaxation of the k-selection rule, tail states, dangling bonds etc. were added to the vocabulary of practitioners in the field; it would not be too generous to give Mott credit for introducing most of these ideas. Another significant event in the development of the subject was the discovery by Spear's group of the way to dope amorph-ous silicon - providing a further boost to worldwide interest and leading to the development of solar cells, thin-film transistors and other devices now used extensively in the electronics industry. This year (1997) sees the 17th. conference in the same series mentioned above, the only change being to its name it is now the "International Conference on Amorphous and Microcrystalline

Semiconductors", but it will still start with the "Mott lecture".

Mott's work in the above field was not interrupted by his retirement in 1971 . The first edition of a book, co-authored with the present writer, "Electronic Processes in Non-Crystalline Materials" was published in that year and a second edition, extensively rewritten, appeared in 1979. In the intervening years he had also written "Metal-Insulator Transitions" (1974) and a book for sixth formers "Elementary Quantum Mechanics" (1972). When the Cavendish Laboratory moved from its old home in Free School Lane to its present site in West Cambridge, Mott collaborated with Abe Yoffe and Mike Pepper in their respective studies of low-dimensional crystals and silicon inversion layers, as well as with numerous long-stay visitors who were attracted to Cambridge by his late bursts of scientific activity and the interest he showed in their work.

\section{Final decades}

During the late 1980s, Mott turned his attention to another major field of scientific discovery - that of hightemperature superconductivity. In this endeavour he collaborated principally with Sasha Alexandrov - a Russian theoretician, for whom Mott was able to find a position in the Cavendish financed by a college fellowship and with whom he wrote two more books. The field is still too new to assess Mott's contributions to the subject but, whatever future scientific judgement be cast on them, he continued to stimulate and inspire colleagues, both young and old, in his unforgettable manner and by his wise counsel until well past his ninetieth birthday - an astonishing achievement.

Throughout his long career, Mott's energy and enthusiasm pervaded much of twentieth century physics. His appetite for new challenges seemed inexhaustible and his contributions to science will be quoted well into the next millenium. But what may not be recorded adequately is his influence on the lives and careers of numerous friends and colleagues whom he befriended, advised and guided with such great generosity. He will be sorely missed.

Prof. E.A. Davies, University of Leicester, UK
Prof. Dr. phil., Dr. h. c. mult. Friedrich Hund

*4. Februar 1896 +31. Mărz 1997

Die Wissenschaft war Mitte seines Lebens.

Wir travern um unseren Vater, Großvater und Urgroßvater

Gerhard und Juliane Hund

Irmgard und Prot. Dr. Dieter Pfirsch

Dr. Martin und Rita Hund Andreas Hund

Dr. Erwin und Karola Hund

Enkel und Urenke

Charlottenburger Straße 19 (GDA-Wohnstift), 37070 Göttingen

Die Traverteier findet am Mitwoch, dem 9. Aprit 1997, um 12.00 Uhr in der groben Kapelle des Städt. Fnedhols Gôttingen Junkerberg (OT Weende-Nord) stat. 